\title{
Cavity-tree use and frequency of response to playback by the Tropical Screech-Owl in northwestern Argentina
}

\author{
Alejandro A. Schaaf ${ }^{1}$, Ever Tallei ${ }^{1}$, Natalia Politi ${ }^{1}$, Luis Rivera $^{1}$ \\ 1 Universidad Nacional de Jujuy. Consejo Nacional de Investigaciones Científicas y Técnicas (CONICET). \\ Instituto de Ecorregiones Andinas (INECOA). Av. Bolivia 1239, 4600, San Salvador de Jujuy, Jujuy, \\ Argentina; Fundación CEBio. Roca 44, San Salvador de Jujuy 4600, Jujuy, Argentina \\ Corresponding author: Alejandro A. Schaaf (schaaf.alejandro@gmail.com)
}

Academic editor: A. M. Leal-Zanchet | Received07 March2018 | Accepted23 December 2018 | Published 11 April2019

Citation: Schaaf AA, Tallei E, Politi N, Rivera L (2019) Cavity-tree use and frequency of response to playback by the Tropical Screech-Owl in northwestern Argentina. Neotropical Biology and Conservation, 14(1): 99-107. https://doi.org/10.3897/neotropical.14.e34839

\begin{abstract}
The Tropical Screech-Owl (Megascops choliba) is a nocturnal raptor with a wide distribution across the Neotropics, which uses cavity trees as nesting and roosting sites. Our objectives were to address cavity use by the Tropical Screech-Owl in the piedmont forest of Argentina and to evaluate if logging affects the availability of suitable cavities for nesting and roosting and the frequency of response of the species to playback. The Tropical Screech-Owl used trees with DBH values $>46 \mathrm{~cm}$ of three tree species (69\% Calycophyllum multiflorum, 15\% Phyllostylon rhamnoides, and 8\% Cedrela angustifolia), besides standing dead trees (8\%). The density of suitable cavities was significantly lower in logged forests than in the control site. The frequency of response of the species to playback was significantly lower at one logged site. Our results can contribute to delineate sustainable forest management to ensure the conservation of this owl in logged forest.
\end{abstract}

\section{Keywords}

Cavity-nesting birds, Forest management, Neotropical Owls, Yungas, Argentina 


\section{Introduction}

Many bird species depend on the presence of cavities for nesting, sheltering or roosting (Martin et al. 2004; Collias \& Collias, 2014). Thus, the abundance of these birds might be affected if the numbers of available cavities decrease (LaManna and Martin, 2017; Van der Hoek et al. 2017). Unsustainable logging can decrease the abundance of available cavities (Politi et al. 2012), therefore, it is important to assess the impact of this economic activity on biodiversity, especially in tropical and subtropical forests of the Neotropics, where the area under logging has increased (Hansen et al. 2013; Van der Hoek et al. 2017).

Nocturnal forest raptors are particularly sensitive to habitat change due to their specific nesting requirements and their large home ranges (Jullien and Thiollay, 1996; Rivera-Rivera et al. 2012). Moreover, nocturnal raptors play a key role in the ecosystem as top predators in trophic chains (Bildstein, 2001; Sergio et al. 2008). The Tropical Screech-Owl (Megascops choliba; Strigidae) is a nocturnal raptor which uses cavities as nesting sites and has a large distribution range from Costa Rica to central Argentina (Holt et al. 1999; Trejo et al. 2012). However, little is known about Tropical Screech-Owl habitat requirements (Dias and Lima, 2015). In Argentina, only anecdotal information exists on Tropical Screech-Owl cavity tree use and other nesting characteristics (de la Peña, 2005; Ruggera et al. 2016). Although the species is not categorized as threatened, forest degradation and transformation can negatively affect owl populations in Argentina (Trejo et al. 2012). Our objectives were to evaluate use and availability of tree cavity and frequency of responses of the Tropical Screech-Owl to playback in logged Piedmont forest of northwestern Argentina. We predict that logged forests will result in a lower availability of suitable cavities for Tropical Screech-Owl, and lower species' frequency of responses to playback.

Fieldwork was conducted in the Piedmont forests of Jujuy and Salta provinces in Argentina (Figure 1). This subtropical forest is found between 400 and 900 meters a.s.l. and is characterized by a highly seasonal climate, with annual rainfall values between 800 and $1000 \mathrm{~mm}$ concentrated during the summer between January and March (Arias and Bianchi, 1996). We selected four sites: one control located in Calilegua Nacional Park which has not been under logging for more than 40 years (Site $1: 23^{\circ} 38.181^{\prime} \mathrm{S}, 64^{\circ} 35.674^{\prime} \mathrm{W}$ ), and three others that are currently under conventional logging (Site 2: $22^{\circ} 27.255^{\prime} \mathrm{S}, 63^{\circ} 58.553^{\prime} \mathrm{W}$; Site $3: 22^{\circ} 05.373^{\prime} \mathrm{S}$, $63^{\circ} 44.810^{\prime} \mathrm{W}$; Site $4: 24^{\circ} 11.435^{\prime} \mathrm{S}, 64^{\circ} 34.449^{\prime} \mathrm{W}$ ) (Figure 1). The sites are dominated by typical tree species of the Piedmont forest; such as Calycophyllum multiflorum, Phyllostylon rhamnoides, Anadenanthera colubrina, Myroxylon peruiferum, and Astronium urundeuva (Brown and Malizia, 2004).

At each site, we delimited an area of 100 ha where we conducted intensive searches for cavities used by the Tropical Screech-Owl during three consecutive breeding seasons from August to February (2014 to 2017). Searches were conducted along 4 to 6 transects per site of 1 to $1.5 \mathrm{~km}$ length and of 20 to $50 \mathrm{~m}$ wide. Encountered cavities were inspected with a mini-camera system attached to a $15 \mathrm{~m}$ 


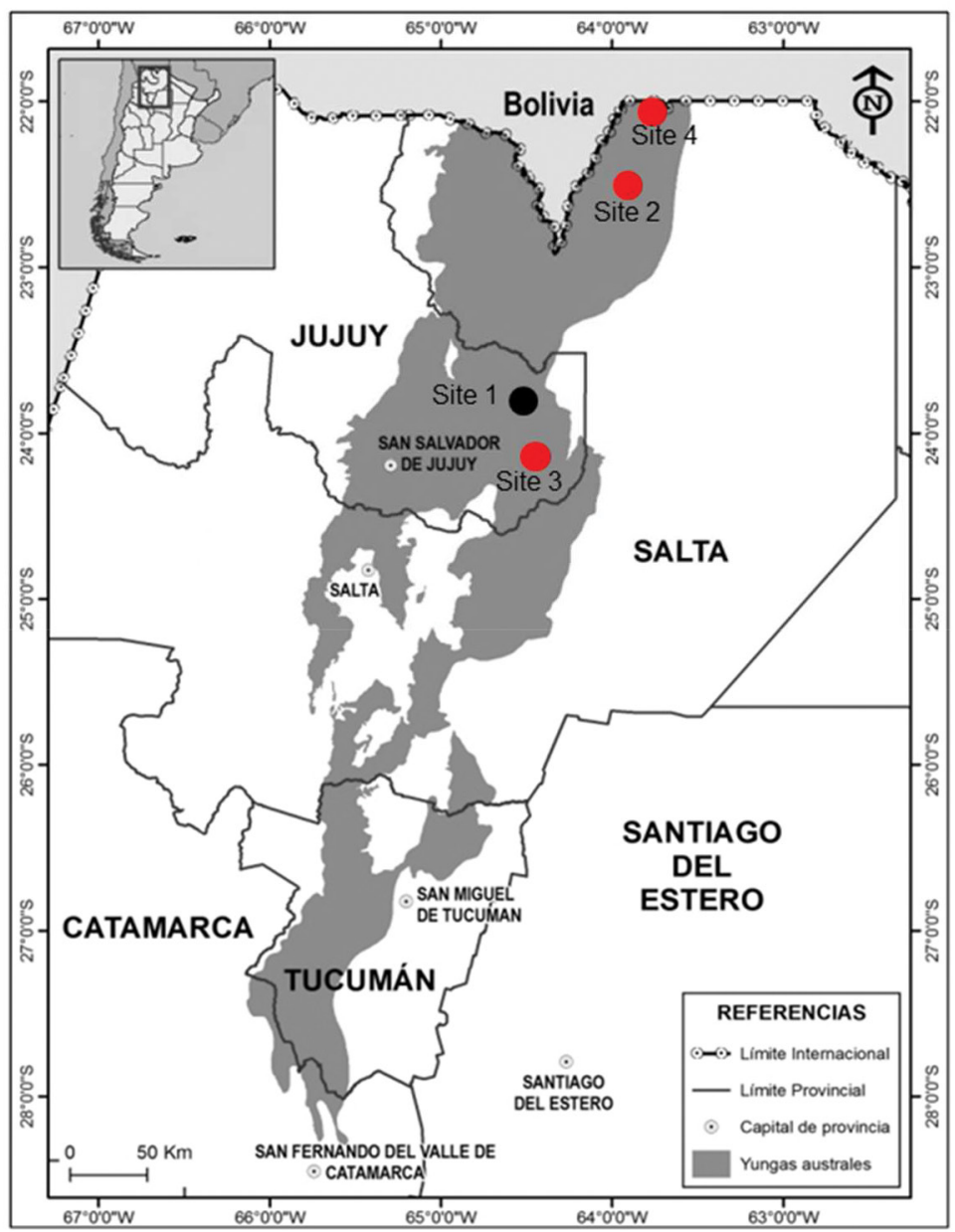

Figure 1. Location of the different study sites in the Piedmont forest of northwestern Argentina. Control site (1) and sites under logging (2, 3 and 4).

extendable pole (Richardson et al. 1999) to determine if they were used. In order to define suitable cavities for the Tropical Screech-Owl for each used cavity encountered we determined tree species and cavity origin (excavated by Woodpecker or decayed) and we measured tree diameter at breast height (DBH), cavity entrance height above the ground, horizontal and vertical entrance diameter (to determine cavity entrance area by using the formula of an ellipse), and internal cavity depth (Politi et al. 2010; Ruggera et al. 2016).

To determine the availability of suitable cavities for the Tropical Screech-Owl, we randomly selected $50 \times 50$ m plots ( 10 plots in sites 1 and 3 and 20 plots in sites 2 and 4) from a 100 ha grid (Politi et al. 2010). Suitable cavities were defined according to the characteristics used by the species, based on the range values of each characteristic defined in the result section. 
At each site and within the 100 ha grid, we conducted 15 point counts to record the Tropical Screech-Owl from October 2016 to January 2017 in coincidence with the reproductive period of the species. Point counts were separated by at least $150 \mathrm{~m}$, because of a minimum of $100 \mathrm{~m}$ is considered enough to avoid overestimation of individuals or the re-count of individuals (Borges et al. 2004). Point counts at each site were carried out during two or three consecutive days between $8 \mathrm{~h}$ and $11 \mathrm{~h}$ p.m., in coincidence with the highest peak of activity of nocturnal raptors. At each point count, we broadcasted a recording of the owl vocalizations (extracted from Xeno-canto Foundation 2008) for 10 minutes to elicit a vocal or visual response (Fuller and Mosher, 1987). We recorded frequency of responses of the Tropical Screech-Owl within a $50 \mathrm{~m}$ radius during the 10 minutes. Point counts were not conducted in adverse weather conditions (Hardy and Morrison, 2000; Rivera-Rivera et al. 2012). The number of responses of the Tropical Screech-Owl at each point count was used to calculate the frequency of responses at each site.

We compared the frequency of responses of Tropical Screech-Owl, the density of used cavities, cavity and tree characteristics (tree DBH, cavity height, cavity entrance size) of used cavities, and the density of used cavity trees species between sites with a Kruskal-Wallis test $(\mathrm{H})$ due to the non-normal distribution of the data. All comparisons were performed with the INFOSTAT software, using a significance level of 0.05 (Di Rienzo et al. 2002).

We found a total of 13 cavities used by the Tropical Screech-Owl in decayed cavities in the following tree species: Calycophyllum multiflorum (69\%), Phyllostylon rhamnoides (15\%), and Cedrela angustifolia (8\%), as well as in standing dead trees (8\%). Used cavities were found in trees with a DBH of $47.83 \pm 2.42 \mathrm{~cm}$ $($ range $=46.12-49.54 \mathrm{~cm})$, cavity entrance height of $5.20 \pm 0.75 \mathrm{~m}($ range $=4.67-$ $5.73 \mathrm{~m})$, and cavity entrance area of $283.39 \pm 81.04 \mathrm{~cm}^{2}\left(\right.$ range $\left.=226.08-340.69 \mathrm{~cm}^{2}\right)$ with a cavity depth $>10 \mathrm{~cm}$. The frequency of responses of the Tropical ScreechOwl was significantly higher in control site than in logged site $4(\mathrm{H}=8.58 ; \mathrm{p}<0.05)$ (Figure 2). The control site showed a significantly higher density of suitable cavities, higher DBH values, and higher density of suitable cavities of C. multiflorum and $P$. rhamnoides than logged sites (Table 1).

In logged Piedmont forest the lower availability of cavities suitable for the Tropical Screech-Owl may explain the lower frequency of responses to playback of the species as shown for other nocturnal raptors (Carrete et al. 2009). Calycophyllum multiflorum, Phyllostylon rhamnoides, and Cedrela angustifolia are highly valuable timber species and, consequently, have a high removal rates in logged sites resulting in a decrease in the density of these tree species (Politi et al. 2010). In site 4 we did not find cavity trees available of $P$. rhamnoides or $C$. angustifolia. In addition, the density of C. multiflorum with cavities was lower and cavity trees always had lower DBH values (Table 1). The frequency of the owl's response to playback may not have differed between the logged sites 2 and 3, and the control because there still are available cavities in P. rhamnoides, C. angustifolia, and standing dead trees. 


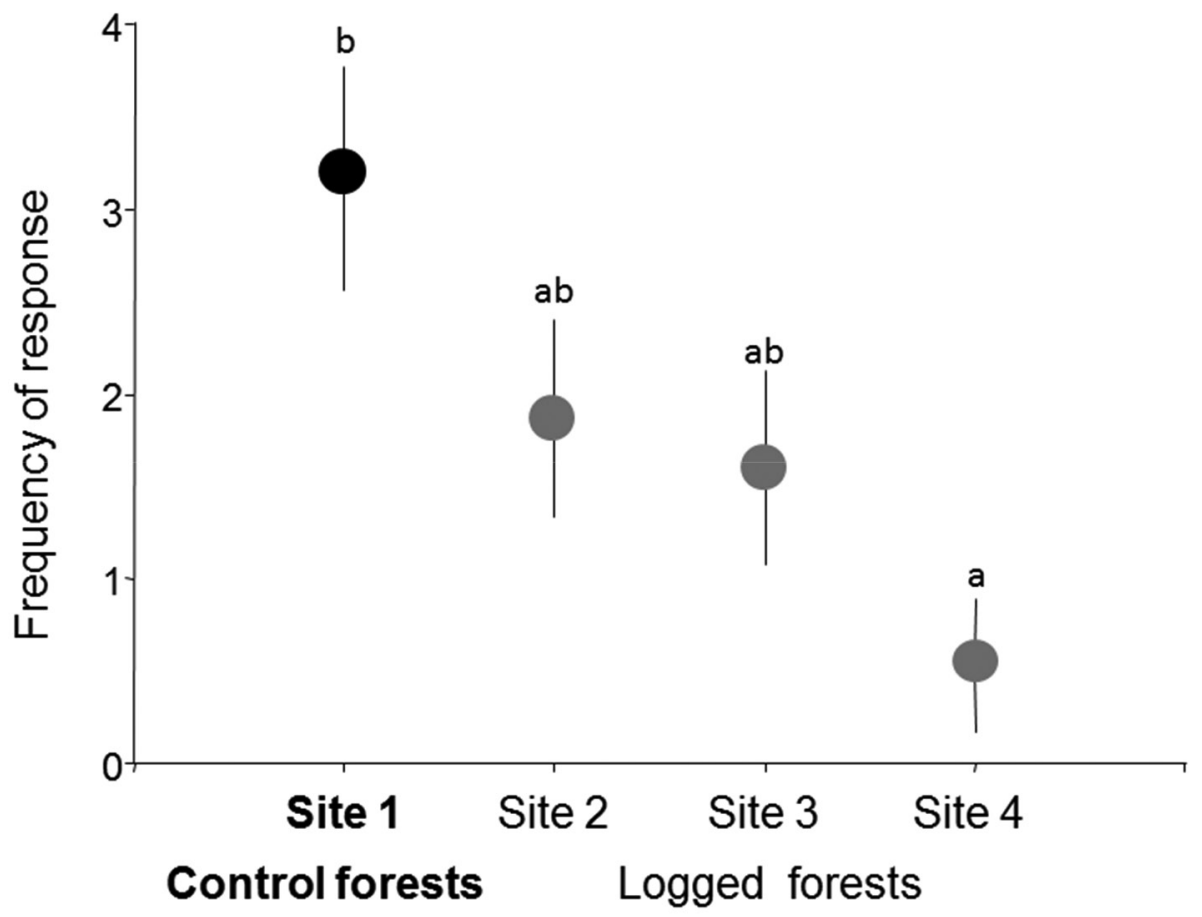

Figure 2. Frequency of response of the Tropical Screech-Owl in point count (mean \pm SE) using Raptor calls technique (playback) in three logged sites and one control site (not logged) in the Piedmont forest of northwestern Argentina. Different letters indicate significant differences between sites (Kruskal-Wallis tests; $\mathrm{p}<0.05$ ).

Logging operations in the Piedmont forest should retain trees of $46-50 \mathrm{~cm} \mathrm{DBH}$ of those tree species which is the minimum size required by the Tropical ScreechOwl. The importance of large trees has already been stated for other cavity nesting bird species inhabiting the Piedmont forest (Albanesi et al. 2016; Ruggera et al. 2016). Although the Tropical Screech-Owl has been suggested to be a generalist species (de la Peña, 2005), it is worth noting its narrow tree size requirements (46$50 \mathrm{~cm} \mathrm{DBH}$ ), indicating that it may be a specialist species in the Piedmont forests regarding cavity tree requirements (Claudino et al. 2012; Dias and Lima, 2015).

While the results suggest the existence of a threshold in Piedmont forests regarding the density of suitable cavities ( 0.40 cavity/ha), below which the frequency of response to playback of this Owl decreases, it is necessary to point out that this particular species can be found in diverse environments (e.g., Open forest, urban parks or plantations; de la Peña, 2005; Enriquez, 2017). Therefore, thresholds cannot be generalized to other environments and further research is needed. The results of this study can be useful to delineate sustainable forest management guidelines to ensure the conservation of Tropical Screech-Owl and other biodiversity components in logged forests (Lindenmayer, 2000; Politi et al. 2009, 2010). 
Table 1. Characteristics of trees and cavities suitable for the Tropical Screech-Owl and cavity density /ha in three logged sites and one control site in the Piedmont forests of northwestern Argentina. $n=$ total plots; different superscript letters indicate significant differences between sites (Kruskal-Wallis tests; $\mathrm{p}<0.05)$.

\begin{tabular}{lccccc}
\hline & $\begin{array}{c}\text { Control site } \\
\text { Site 1 } \\
\mathbf{n = 1 0}\end{array}$ & $\begin{array}{c}\text { Logged sites } \\
\text { Site 2 } \\
\mathbf{n = 2 0}\end{array}$ & $\begin{array}{c}\text { Site 3 } \\
\mathbf{n = 2 0}\end{array}$ & $\begin{array}{c}\text { Site 4 } \\
\mathbf{n = 1 0}\end{array}$ & H \\
& $56.95 \pm 11.97^{\mathrm{b}}$ & $38.26 \pm 3.200^{\mathrm{a}}$ & $33.45 \pm 2.67^{\mathrm{a}}$ & $33.33 \pm 3.320^{\mathrm{a}}$ & 12.89 \\
\hline Cavity tree DBH $(\mathrm{cm})$ & $8.25 \pm 2.89^{\mathrm{a}}$ & $6.04 \pm 0.95^{\mathrm{a}}$ & $5.85 \pm 0.21^{\mathrm{a}}$ & $4.62 \pm 0.87^{\mathrm{a}}$ & 4.70 \\
Cavity entrance height $(\mathrm{m})$ & $665.70 \pm 672.92^{\mathrm{a}}$ & $233.81 \pm 55.62^{\mathrm{a}}$ & $216.49 \pm 26.15^{\mathrm{a}}$ & $199.16 \pm 30.08^{\mathrm{a}}$ & 4.84 \\
Cavity entrance area $\left(\mathrm{cm}^{2}\right)$ & $4.80 \pm 4.17^{\mathrm{b}}$ & $0.80 \pm 2.53^{\mathrm{a}}$ & $0.60 \pm 1.47^{\mathrm{a}}$ & $0.4 \pm 1.23^{\mathrm{a}}$ & 9.39 \\
Total cavity tree /ha & $1.60 \pm 2.07^{\mathrm{b}}$ & $0.40 \pm 1.23^{\mathrm{a}}$ & $0^{\mathrm{a}}$ & $0.4 \pm 1.26^{\mathrm{a}}$ & 3.2 \\
Cavity tree/ha of C. multiflorum & $2.00 \pm 2.83^{\mathrm{b}}$ & $0.20 \pm 0.89^{\mathrm{a}}$ & $0.20 \pm 0.89^{\mathrm{a}}$ & $0^{\mathrm{a}}$ & 3.93 \\
Cavity tree/ha of P. rhamnoides & $0.40 \pm 1.26^{\mathrm{a}}$ & $0^{\mathrm{a}}$ & $0.20 \pm 0.89^{\mathrm{a}}$ & $0^{\mathrm{a}}$ & 0.25 \\
Cavity tree/ha of C. balansae & $0.80 \pm 1.69^{\mathrm{a}}$ & $0.20 \pm 0.89^{\mathrm{a}}$ & $0.20 \pm 0.89^{\mathrm{a}}$ & $0^{\mathrm{a}}$ & 0.69 \\
Cavity tree/ha of snags & & & & & \\
\hline
\end{tabular}

\section{Acknowledgments}

We thank National Park Administration of Argentina for allowing us to work in Calilegua National Park. Thanks to Cecilia García and Thaís Bonato de Arruda for their comments on the manuscript and all the people who helped with the fieldwork, for their big effort and support. We want to thank the anonymous reviewers for their detailed comments, which have greatly improved the quality of the manuscript. Fieldwork was supported with funds from Agencia Nacional de Promoción Científica y Tecnológica (PICT 2012-0892, BID, PICT 2014-1388, BID), CONICET (PIP 112-201201-00259 CO) and CONICET-UNJU (PIO 1402014100133), and UNJU (SECTER B 046). Also, Idea Wild, Association of Field Ornithologists, Optic for the Tropic and Rufford Small Grants.

\section{References}

ARIAS, M.; BIANCHI, A. R. 1996. Estadísticas climatológicas de la Provincia de Salta. Gobierno de Salta, Dirección de Medio Ambiente y Recursos Naturales, 189 p.

BILDSTEIN, K. L. 2001. Why migratory birds of prey make great biological indicators. Hawkwatching in the Americas. North Wales, Hawk Migration Association of North America, p. 169-179.

BORGES, S. H.; HENRIQUES, L. M.; CARVALHAES, A. 2004. Density and Habitat Use by Owls in Two Amazonian Forest Types (Densidad y uso de habitat por varias especies de búhos en dos tipos de bosques amazónicos). Journal of Field Ornithology, 75 (2):176182. https://doi.org/10.1648/0273-8570-75.2.176

BROWN, A. D.; MALIZIA, L. R. 2004. Las selvas pedemontanas de las Yungas. Ciencia hoy, 14(83): 52-63. 
CARRETE, M.; TELLA, J. L.; BLANCO, G.; BERTELLOTTI, M. 2009. Effects of habitat degradation on the abundance, richness and diversity of raptors across Neotropical biomes. Biological Conservation, 142(10): 2002-2011. https://doi.org/10.1016/j.biocon.2009.02.012

CLAUDINO, R. M.; RODRIGUES, R. C.; BIZ SILVA, M. R. 2012. New record of nesting site of tropical screech owl (Megascops choliba) from Brazil. Ornitologia Neotropical, 23(1): 137-141.

COLLIAS, N. E.; COLLIAS, E. C. 2014. Nest building and bird behavior. New Jersey, Princeton University Press, $358 \mathrm{p}$.

DE LA PEÑA, M. 2005. Reproducción de las aves argentinas (con descripción de pichones). LOLA, Buenos Aires, Argentina.

DI RIENZO, J.; BALZARINI, M.; GONZÁLEZ, I.; TABLADA, M.; GUZMÁN, W.; ROBLEDO, C.; CASANOVES, F. 2002. Software Infostat Versión 1.1. Grupo Infostat, Universidad Nacional de Córdoba, Argentina.DIAS, R. I.; LIMA, M. R. 2015. Breeding biology and nest survival in Tropical Screech-Owls (Megascops choliba) in the Brazilian Cerrado. The Wilson Journal of Ornithology, 127(3): 432-440. https://doi.org/10.1676/14-099.1

ENRIQUEZ, P. L. 2017. Neotropical Owls: Diversity and Conservation. Switzerland, Springer, 670 p. https://doi.org/10.1007/978-3-319-57108-9

FULLER, M. R.; MOSHER, J. A. 1987. Raptor survey techniques. Washington, US Fish and Wildlife Service, pp. 37-65

HANSEN, M. C.; POTAPOV, P. V.; MOORE, R.; HANCHER, M.; TURUBANOVA, S.; TYUKAVINA, A.; THAU, D.; STEHMAN, S.V.; GOETZ, S.J.; LOVELAND, T.R.; KOMMAREDDY, A.; EGOROV, A.; CHINI, L.; JUSTICE, C.O.; TOWNSHEND, J.R.G. 2013. High-resolution global maps of $21^{\text {st }}$-century forest cover change. Science, 342(6160): 850-853. https://doi.org/10.1126/science.1244693

HARDY, P. C.; MORRISON, M. L. 2000. Factors affecting the detection of elf owls and western screech owls. Wildlife Society Bulletin, 28: 333-342. https://doi.org/10.1002/jwmg.192

HERRANDO, S.; WEISERBS, A.; QUESADA, J.; FERRER, X.; PAQUET, J. Y. 2012. Development of urban bird indicators using data from monitoring schemes in two large European cities. Animal Biodiversity and Conservation, 35(1): 141-150.

HOLT, D. W.; BERKELY, R.; DEPPE, C.; ENRIQUEZ-ROCHA, P. L.; OLSEN, P. D.; PETERSON, J. L.; ...WOOD, K. L. 1999. Ferruginous pygmy-owl. In: J.Hoyo ; A. Elliot, ; J.Sargatal (eds.) Handbook of the Birds of the World, vol. 5. Barcelona, Lynx Edicions, 217 p.

JULLIEN, M.; THIOLLAY, J. M. 1996. Effects of rain forest disturbance and fragmentation: comparative changes of the raptor community along natural and human-made gradients in French Guiana. Journal of Biogeography, 23(1): 7-25. https://doi.org/10.1046/ j.1365-2699.1996.00963.x

LAMANNA, J. A.; MARTIN, T. E. 2017. Logging impacts on avian species richness and composition differ across latitudes and foraging and breeding habitat preferences. Biological Reviews, 92(3): 1657-1674. https://doi.org/10.1111/brv.12300

LINDENMAYER, D. B.; MARGULES, C. R.; BOTKIN, D. B. 2000. Indicators of biodiversity for ecologically sustainable forest management. Conservation biology, 14(4): 941-950. https://doi.org/10.1046/j.1523-1739.2000.98533.x 
MARTIN, K.; AITKEN, K. E.; WIEBE, K. L. 2004. Nest sites and nest webs for cavity-nesting communities in interior British Columbia, Canada: nest characteristics and niche partitioning. The condor, 106(1): 5-19. https://doi.org/10.1650/7482

POLITI, N.; HUNTER JR, M.; RIVERA, L. 2009. Nest Selection by Cavity-nesting Birds in Subtropical Montane Forests of the Andes: Implications for Sustainable Forest Management. Biotropica, 41(3): 354-360. https://doi.org/10.1111/j.1744-7429.2008.00481.x

POLITI, N.; HUNTER JR, M.; RIVERA, L. 2010. Availability of cavities for avian cavity nesters in selectively logged subtropical montane forests of the Andes. Forest Ecology and Management, 260(5), 893-906. https://doi.org/10.1016/j.foreco.2010.06.009

POLITI, N.; HUNTER, M.; RIVERA, L. 2012. Assessing the effects of selective logging on birds in Neotropical piedmont and cloud montane forests. Biodiversity and Conservation, 21(12): 3131-3155. https://doi.org/10.1007/s10531-012-0358-3

RICHARDSON, D. M.; BRADFORD, J. W.; RANGE, P. G.; CHRISTENSEN, J. 1999. A video probe system to inspect Red-cockaded Woodpecker cavities. Wildlife Society Bulletin (1973-2006), 27(2), 353-356.

RENWICK, A. R.; JOHNSTON, A.; JOYS, A.; NEWSON, S. E.; NOBLE, D. G.; PEARCEHIGGINS, J. W. 2012. Composite bird indicators robust to variation in species selection and habitat specificity. Ecological Indicators, 18: 200-207. https://doi.org/10.1016/j. ecolind.2011.11.008

RUGGERA, R. A.; SCHAAF, A. A.; VIVANCO, C. G.; POLITI, N.; RIVERA, L. O. 2016. Exploring nest webs in more detail to improve forest management. Forest Ecology and Management, 372, 93-100. https://doi.org/10.1016/j.foreco.2016.04.010

SERGIO, F.; CARO, T.; BROWN, D.; CLUCAS, B.; HUNTER, J.; KETCHUM, J.; MCHUGH, K.; HIRALDO, F. 2008. Top predators as conservation tools: ecological rationale, assumptions, and efficacy. Annual review of ecology, evolution, and systematics, 39: 1-19. https://doi.org/10.1146/annurev.ecolsys.39.110707.173545

TREJO, A.; BÓ, M. S.; BIONDI, L. 2012. Búhos de Argentina: estado de conservación y prioridades de investigación. Ornitología Neotropical, 23; 225-232.

VAN DER HOEK, Y.; GAONA, G. V.; MARTIN, K. 2017. The diversity, distribution and conservation status of the tree-cavity-nesting birds of the world. Diversity and Distributions, 23(10): 1120-1131. https://doi.org/10.1111/ddi.12601

XENO-CANTO FOUNDATION. 2008. Xeno-canto America. Bird sounds for the Americas.

Xeno-canto Foundation, Amsterdam (URL: http://www.xeno-canto.org/index_static. html). Accessed on: July 2016.

\section{Resumo}

\section{Uso de cavidades arbóreas e frequência de resposta a playback pela corujinha- do-mato em região noroeste da Argentina}

A corujinha-do-mato (Megascops choliba) é uma ave de rapina com hábitos noturnos e uma ampla distribuição neotropical que utiliza cavidades arbóreas para nidificação e alojamento. Nosso objetivo foi identificar o uso de cavidades pela corujinha-do- 
mato na floresta piemonte na Argentina, e avaliar se a atividade exploratória afeta a disponibilidade de cavidades adequadas para nidificação e alojamento, bem como a frequência de resposta desta espécie. A corujinha-do-mato utiliza árvores com valores DAP $>46 \mathrm{~cm}$ para três espécies de árvores (69\% Calycophyllum multiflorum, 15\% Phyllostylon rhamnoides, e 8\% Cedrela angustifolia), além de árvores mortas eretas (8\%). A densidade de cavidades adequadas foi significativamente menor em florestas exploradas quando comparadas ao local de controle. A frequência de resposta foi significativamente menor em um sítio de exploração. Os resultados descritos aqui reforçam a importância do manejo florestal sustentável a fim de garantir a persistência dessa espécie de ave.

\section{Palavras-chave}

Aves nificadoras em cavidades, manejo florestal, coruja tropical, Yungas, Argentina 
